\begin{tabular}{|l|l|l|}
\hline \multicolumn{2}{|c|}{ PublisherInfo } \\
\hline \hline PublisherName & $:$ & BioMed Central \\
\hline \hline PublisherLocation & $:$ & London \\
\hline \hline PublisherImprintName & $:$ & BioMed Central \\
\hline \hline
\end{tabular}

\title{
Journal trio embraces MIAME
}

\begin{tabular}{|l|l|l||}
\hline \multicolumn{2}{|c|}{ ArticleInfo } \\
\hline \hline ArticleID & $:$ & 4606 \\
\hline \hline ArticleDOI & $:$ & $10.1186 /$ gb-spotlight-20021010-01 \\
\hline \hline ArticleCitationID & $:$ & gb-spotlight-20021010-01 \\
\hline \hline ArticleSequenceNumber & $:$ & 272 \\
\hline \hline ArticleCategory & $:$ & Research news \\
\hline \hline ArticleFirstPage & $:$ & 1 \\
\hline \hline ArticleLastPage & $:$ & 3 \\
\hline \hline & & RegistrationDate : 2002-10-10 \\
ArticleHistory & $:$ & OnlineDate \\
\hline \hline ArticleCopyright & $:$ & BioMed Central Ltd2002-10-10 \\
\hline \hline ArticleGrants & $:$ & \\
\hline \hline ArticleContext & $:$ & 130593311 \\
\hline \hline
\end{tabular}


In response to a request from the Microarray Gene Expression Data Society (MGED), the journals Nature, Cell, and The Lancethave adopted MGED's guidelines for submitting microarray expression data for publication. MGED developed the guidelines known as MIAME (Minimum Information About a Microarray Experiment) to facilitate the interpretation and verification of microarray results.

"Harried editors can rejoice that, at last, the community is taming the unruly beast that is microarray information," Nature editors wrote of the MIAME standard in a recent issue of the journal (419:232).

According to Cell editor, Vivian Siegel, the challenge for journals has been to figure out exactly what aspects of the data needed to be provided to their readers. "We were very much in the dark about just what you need to make the work useful to other people. That's where the MIAME guidelines have been really helpful," Siegel told us.

MIAME may evolve, as researchers and journals work with it, but as it stands now, MIAME requires information on experimental design, sample preparation and labeling, hybridization procedures and parameters, measurement data and specifications, and array design - dozens of bits of information. To make it as easy as possible for researchers to be MIAME compliant, MGED has developed a checklist, available on the organization's web site, and has also developed a mark-up language, MAGE-ML, for communicating MIAME-compliant data.

In addition to demanding MIAME-compliant data, Nature and Cell will require authors to submit their microarray data to a public repository as a precondition for publication. At present, there are two main public international sites: the Gene Expression Omnibus (GEO) at the National Center for Biotechnology Information (NCBI), and ArrayExpress at the European Bioinformatics Institute (EBI). This is necessary, according to Cell's Siegel, and a better solution than the journals holding the information, as the repositories will guarantee an archive.

The biggest impediment to large-scale analysis of microarray data is the lack of a common data format, agreed David Haussler, Director of the Center for Biomolecular Science and Engineering at University of California, Santa Cruz, agrees. "The simple requirement that you had to submit your [DNA] sequence [to a public repository] has already done wonders for computational biology," he said. "That was a small, but very significant step. Now we're taking a significantly larger step."

Genome Biology will not yet go beyond strongly urging all authors of microarray articles to submit their data to one of the public gene expression data repositories. Theodora Bloom, editor for Genome Biology, said that although the journal has always insisted on the public availability of the data relevant to all research articles, "our understanding is that the public repositories of gene expression data are not yet as user-friendly nor as standardized as the GenBank/EMBL/DDBJ trio of databases for DNA sequences."

Neither Science nor Proceedings of the National Academy of Sciences $(P N A S)$ will be adopting the MIAME format at present, though according to Deborah Sullenberger, executive editor for $P N A S$, it is on their radar screen. Science senior staff writer Rebecca Ham told us that the journal plans to publish 
letters from some of the groups working with microarrays, creating a forum for feedback and discussion among a broader group of researchers - something that she said hasn't happened yet.

MGED board member Paul Spellman was "pleasantly surprised" by Nature's quick response and timeframe for implementation. (Papers submitted to Nature after December 1 must comply.) He had predicted that because of its complexity, MIAME might be a hard sell to journals. "Science's reaction was more in the lines of what I expected; belief that it was reasonable, but in need of broader airing," he told us.

\section{References}

1. Microarray Gene Expression Data Society, [http://www.mged.org/]

2. Nature, [http://www.nature.com/nature/]

3. Cell, [http://www.cell.com]

4. The Lancet, [http://www.thelancet.com/home]

5. L. DeFrancesco: "MIAME begets MAGE," The Scientist, 17 September, 2002, [http://www.thescientist.com/news/20020917/02/]

6. Gene Expression Omnibus, National Center for Biotechnology Information, [http://www.ncbi.nlm.nih.gov/geo/]

7. ArrayExpress, European Bioinformatics Institute, [http://www.ebi.ac.uk/microarray/ArrayExpress/ arrayexpress.html]

8. Center for Biomolecular Science and Engineering, University of California, Santa Cruz, [http://www.cse.ucsc.edu/centers/cbe/]

9. Genome Biology, [http://www.genomebiology.com/start.asp]

10. Science, [http://www.sciencemag.org/]

11. Proceedings of the National Academy of Sciences, [http://www.pnas.org] 